\title{
Economic impacts of space allowance per animal on beef cattle feedlot
}

\section{Impactos econômicos do espaço disponível por animal em confinamentos bovinos}

\author{
Natalia Ludmila Lins Lima Montelli ${ }^{1}$; Fernanda Macitelli²; Janaina da Silva \\ Braga $^{3}$; Mateus José Rodrigues Paranhos da Costa ${ }^{4 *}$
}

\begin{abstract}
The objective of this study was to assess the economic outcomes of three space allowances $(6,12$, and $24 \mathrm{~m}^{2}$ per animal) for outdoor feedlots-finished beef cattle. Simulations considered confinement systems with a static capacity of 5,000 animals per cycle and two 86-day cycles per year. Performance data were obtained from 1,350 uncastrated bovine males. An increase in space allowance elevated the fixed cost per animal. Fixed and variable costs represented 3\% and $93 \%$ of the total operating cost, respectively. For variable costs, around $70 \%$ was used for purchasing cattle and $17 \%$ for purchasing feed. The operating profit per animal increased as space allowance increased $(\mathrm{R} \$ 80.90, \mathrm{R} \$ 102.00$, and $\mathrm{R} \$ 109.00$ for 6,12 , and $24 \mathrm{~m}^{2}$ per animal, respectively). The three feedlot systems recovered the initial investment and had a positive net present value. In addition, the internal rates of return were $22 \%, 27 \%$, and $25 \%$, and the probabilities of financial loss were $33 \%, 29 \%$, and $26 \%$ for pen sizes of 6,12 , and $24 \mathrm{~m}^{2}$ per animal, respectively. Therefore, larger space allowances improve profitability and reduce the risk of financial loss.
\end{abstract}

Key words: Investment analysis. Risk analysis. Beef cattle. Nellore. Finishing system.

\section{Resumo}

O objetivo com este estudo foi avaliar os resultados econômicos de confinamento de bovinos com três espaços disponíveis por animal $\left(6,12\right.$ e $24 \mathrm{~m}^{2}$ por animal). Para as simulações considerou-se confinamentos com capacidade estática de 5.000 animais por ciclo e dois ciclos de 86 dias por ano. Os dados de desempenho foram obtidos de 1.350 bovinos não castrados. O aumento no espaço elevou o custo fixo por animal. Os custos fixos e variáveis representaram 3\% e $93 \%$ do custo operacional total, respectivamente. Dos custos variáveis, cerca de $70 \%$ foi utilizado para a compra de gado e $17 \%$ para a compra de alimentos. O lucro operacional por animal foi crescente com o aumento na disponibilidade de espaço ( $R \$ 80,90 ; R \$ 102,00$ e $\mathrm{R} \$ 109,00$ para 6,12 e $24 \mathrm{~m}^{2}$ por animal, respectivamente). Os três sistemas de confinamento recuperaram o investimento inicial e apresentaram valor presente líquido positivo. Além disso, as taxas internas de retorno foram de $22 \%, 27 \%$ e $25 \%$, e as probabilidades de perdas financeiras foram de $33 \%, 29 \%$ e $26 \%$ para as dimensões de 6,12 e $24 \mathrm{~m}^{2}$ por animal, respectivamente.

1 Pesquisadora, UNESP, Faculdade de Ciências Agrárias e Veterinária, Programa de Pós-Graduação em Zootecnia, Jaboticabal, SP, Brasil. E-mail: natludmila@yahoo.com.br

2 Prof ${ }^{a}$ Assistente, Universidade Federal do Mato Grosso, UFMT, Rondonópolis, MT, Brasil. E-mail: macitellif@gmail.com

3 Pesquisadora, BEA Consultoria e Treinamento em Produção Animal, Ltda., Rondonópolis, MT, Brasil. E-mail: janainasbraga@ yahoo.com.br

4 Prof., Associado, UNESP, Faculdade de Ciências Agrárias e Veterinárias, Departamento de Zootecnia, Jaboticabal, SP, Brasil. Pesquisador CNPq. E-mail: mateus.paranhos@unesp.br

* Author for correspondence 
Portanto, maior concessão de espaço nos currais de confinamento melhora a rentabilidade e reduz o risco de perda financeira.

Palavras-chave: Análise de investimento, Análise de risco, Bovinos de corte, Nelore, Sistema de terminação.

\section{Introduction}

Cattle finishing in feedlot condition allows a significant increase in productivity per land area, making livestock activity more competitive with agriculture, and serving as a strategy to maintain constant meat supply throughout the year, especially during dry season, when pasture availability and quality are reduced. In Brazil, the number of cattle finished in a feedlot system has increased exponentially, totaling $10 \%$ (four million cattle heads) of the animals slaughtered annually (ANUALPEC, 2016), and this number is estimated to more than double by the next few years, reaching nine million animals (RASMUSSEN et al., 2014).

Despite the production and economic benefits, confinement systems involve transferring cattle from pasture to feedlots, resulting in changes in diet and feeding regime and social regrouping, besides increasing exposure to pathogens and extreme climatic conditions (FELL et al., 1999; MADER, 2003). These factors trigger adaptive mechanisms to maintain homeostasis (MORMÈDE et al., 2007).

Such adaptative responses seem to be influenced by space allowance per animal in feedlot pens. Regarding animal performance, cattle confined in small spaces show decreases in feed intake, food efficiency, and weight gain (INGVARTSEN; ANDERSEN, 1993; FISHER et al., 1997; FELL et al., 1999; HICKEY et al., 2003; GUPTA et al., 2007; MACITELLI, 2015). There is also a higher risk of health problems due to environmental challenges, including dust and mud accumulation in feedlot pens (MACITELLI, 2015). From a behavioral point of view, there is an increase in the frequency of agonistic interactions (KONDO et al., 1989; FISHER et al., 1997) due to the impossibility of animals avoid violating individual space, resulting in higher frequency of aggressive encounters (FRASER, 1980; LINDBERG, 2001).

Despite the above-mentioned results, beef cattle farmers believe that the space required to promote animal welfare is larger than that maximize their profits in confinement systems (VANHONACKER et al., 2008, 2009). In Brazil, feedlot space allowance mostly varies from 10 to $12 \mathrm{~m}^{2}$ per animal (QUINTILIANO; PARANHOS da COSTA, 2006) and there is a trend of decreasing it. Data form the literature have shown feedlot space allowances ranging from 1.2 to $33.0 \mathrm{~m}^{2}$ per animal (GUPTA et al., 2007; MADER, 2011). Despite of the importance of this subject, there are few investigations evaluating the economic impact of feedlot pen space allowance on cattle performance. Therefore, the objective of this study was to assess the economic outcomes of three space allowances $\left(6,12\right.$, and $24 \mathrm{~m}^{2}$ per animal) for outdoor feedlotfinished beef cattle.

\section{Materials and Methods}

Simulations were performed for the implementation of three beef cattle feedlot projects, each of which had different pen space allowances, namely 6,12 , and $24 \mathrm{~m}^{2}$ animal ${ }^{-1}$, being assumed as mutually exclusive projects. The simulations considered that the feedlot projects had a capacity to finish 10,000 animals per year in two 86-days cycles (from May to November), with 150 heads of cattle per pen.

A deterministic method was used assuming fixed values for components of costs, as well as return and risk indicators, taking as a reference data from Mato Grosso State (Brazil) in 2017. The costs and other financial indicators were estimated by using the 
performance indexes obtained by Macitelli (2015), in a commercial feedlot in Rondonópolis, state of when evaluating the growth rate of feedlot-finished Mato Grosso, Brazil (Table 1).

beef cattle kept under the three space allowances

Table 1. Productive performance of feedlot cattle at three space allowances, 6,12 , and $24 \mathrm{~m}^{2}$ per animal.

\begin{tabular}{lcccc}
\hline & & \multicolumn{3}{c}{ Space per animal } \\
\cline { 3 - 5 } Variable & Unit & $6 \mathrm{~m}^{2}$ & $12 \mathrm{~m}^{2}$ & $24 \mathrm{~m}^{2}$ \\
\hline Initial live weight & Arrobas & 13.0 & 13.0 & 13.0 \\
Final live weight & Arrobas & 19.5 & 19.6 & 19.7 \\
Hot carcass weight & $\mathrm{kg}$ & 291.9 & 294.4 & 295.2 \\
Total live weight gain & $\mathrm{kg}$ & 137.6 & 145.3 & 151.5 \\
Average daily weight gain & $\mathrm{kg}^{2}$ animal day & -1 & 1.69 & 1.77 \\
Carcass weight gain & $\mathrm{kg} \mathrm{animal} \mathrm{day}^{-1}$ & 1.60 & 1.16 & 1.18 \\
Mortality & $\%$ & 0.3 & 0.3 & 0.3 \\
Treated animals & $\%$ & 0.5 & 0.5 & 0.2 \\
Cleaning of pens & Machine hours & 2.0 & 1.3 & 0.3 \\
\hline
\end{tabular}

In this study, 1,350 Nellore pure or F1 Aberdeen Angus x Nellore uncastrated bovine males, aged about 30 months and with a mean initial weight of $392 \pm 46 \mathrm{~kg}$, were evaluated. Throughout the confinement period, the animals received two types of diets, the adaptation diet offered during the first 14 days of confinement contained a forage-toconcentrate ratio (F:C) of $64: 36$ and $65 \%$ of total digestible nutrients (TDN), and the finishing diet offered from day 15 until the end of the confinement period contained a F:C of 29:71 and 72\% TDN. All animals used in the study derived from the same herd and were backgrounded in pastures of Brachiaria brizantha cv. Marandu.
For economic analysis, an inventory of all facilities, equipment, and vehicles required for feedlot working routine was prepared (Table 2), and the fixed(FC) and variable costs(VC) werecalculated (Table 3). Asset depreciation was calculated by the linear method (HOFFMANN et al., 1987) using the asset service life according to Barbosa and Souza (2007). To calculate the opportunity cost (OC), the interest rate of the savings account $(6.0 \%$ per year) was used for all variables, including working capital $(50 \%$ of the value of animal purchase plus the remaining effective operating cost). 
Table 2. Coefficients used for estimating financial indicators related to the cost of beef cattle feedlot production at three space allowances, 6,12 , and $24 \mathrm{~m}^{2}$ per animal ${ }^{1}$.

\begin{tabular}{|c|c|c|}
\hline Variables & Units & Coefficients \\
\hline \multicolumn{3}{|l|}{ INVESTIMENT $^{1-2}$} \\
\hline \multicolumn{3}{|l|}{ Facilities, machinery, equipment, and vehicles } \\
\hline Workers' house $\left(300 \mathrm{~m}^{2}\right)^{1}$ & $\mathrm{R} \$ / \mathrm{m}^{2}$ & 915.05 \\
\hline Administrative and other buildings $\left(225 \mathrm{~m}^{2}\right)^{1}$ & $\mathrm{R} \$ / \mathrm{m}^{2}$ & 915.05 \\
\hline Machine shed and feed factory $\left(1.100 \mathrm{~m}^{2}\right)^{1}$ & $\mathrm{R} \$ / \mathrm{m}^{2}$ & 259.46 \\
\hline Corral $\left(450 \mathrm{~m}^{2}\right)^{1}$ & $\mathrm{R} \$ / \mathrm{m}^{2}$ & 259.46 \\
\hline Feedlots pens $(30,60 \text {, and } 120 \mathrm{ha})^{1}$ & $\mathrm{R} \$ / \mathrm{ha}$ & $8,081.10 / 4,160.99 / 2,200.94$ \\
\hline Tractor (1) & $\mathrm{R} \$$ /unit & $140,000.00$ \\
\hline Wagon (1) & $\mathrm{R} \$$ /unit & $200,000.00$ \\
\hline Car (1) & $\mathrm{R} \$$ /unit & $35,000.00$ \\
\hline Motorcycle (1) & $\mathrm{R} \$$ unit & $10,000.00$ \\
\hline Ranch horses (6) & $\mathrm{R} \$$ /animal & $2,000.00$ \\
\hline Farm land (silage: 131 ha) & $\mathrm{R} \$ / \mathrm{ha}$ & $4,400.00$ \\
\hline Paddocks (20 ha) & $\mathrm{R} \$ / \mathrm{ha}$ & $7,400.00$ \\
\hline $\operatorname{Land}^{2}(180,210$, and $270 \mathrm{ha})$ & $\mathrm{R} \$ / \mathrm{ha}$ & $7,400.00$ \\
\hline
\end{tabular}

${ }^{1}$ The full value of the square meter of popular housing (RP1Q) was used to estimate the value of the main house and headquarters, and $50 \%$ of the value of industrial sheds was used to estimate the value of the other facilities (SINDUSCON, 2013), except for feedlots, whose values were estimated according to local surveys and ANUALPEC (2016); ${ }^{2}$ according to ANUALPEC (2016) for the region of Rondonópolis, Mato Grosso, Brazil.

Table 3. Coefficients used for estimating fixed and variable costs of beef cattle feedlot production at three space allowances, 6,12 , and $24 \mathrm{~m}^{2}$ per animal ${ }^{1}$.

\begin{tabular}{|c|c|c|}
\hline Variables & Units & Coefficients \\
\hline \multicolumn{3}{|l|}{ VARIABLE COSTS ${ }^{1-4}$} \\
\hline Purchase of cattle ${ }^{1}$ & $\begin{array}{l}\mathrm{R} \$ \text { per arroba in the first and second production } \\
\text { cycles (April/July) }\end{array}$ & $134.06 / 130.73$ \\
\hline Animal freight & $\mathrm{R} \$$ /animal & 51.40 \\
\hline Feed $^{2}$ (12 kg per animal) & $\begin{array}{l}\mathrm{R} \$ / \mathrm{kg} \text { of dry weight in the first and second } \\
\text { production cycles }\end{array}$ & $0.42 / 0.36$ \\
\hline Health management ${ }^{3}$ & $\mathrm{R} \$$ /animal & 8.85 \\
\hline Treatment of respiratory diseases & $\mathrm{R} \$ /$ sick animal & 78.00 \\
\hline Tagging $^{4}$ & $\mathrm{R} \$$ /animal & 5.46 \\
\hline \multicolumn{3}{|l|}{ Variable taxes } \\
\hline $\begin{array}{l}\text { Fundo de Assistência ao Trabalhador } \\
\text { Rural, Funrural* }\end{array}$ & $\%$ of the total income & 2.30 \\
\hline $\begin{array}{l}\text { Fundo Estadual de Transporte e } \\
\text { Habitação, Fethab* }\end{array}$ & $\mathrm{R} \$$ /animal & 14.93 \\
\hline $\begin{array}{l}\text { Fundo de Apoio à Bovinocultura de } \\
\text { Corte, Fabov* }\end{array}$ & $\mathrm{R} \$$ /animal & 1.60 \\
\hline Cleaning of pens & $\mathrm{R} \$$ per machine hour & 120.00 \\
\hline Other variable costs & $\%$ of total variable costs & 0.50 \\
\hline \multicolumn{3}{|l|}{ FIXED COSTS ${ }^{5-7}$} \\
\hline \multicolumn{3}{|l|}{ Labor $^{5}$} \\
\hline Manager (one) & Four minimum wages/month & $3,748.00$ \\
\hline
\end{tabular}


continuation

\begin{tabular}{lll} 
Employees (nine) & 1.5 minimum wages/month & $1,405.50$ \\
Consultant (one) & 1.0 minimum wage/month & 937.00 \\
Fixed taxes & & \\
IPVA for motorcycles and cars* & \% of the value of the motorcycle or car per year & $2.00 / 4.00$ \\
ITR $^{6 *}$ & \% of the land value per year & 0.07 \\
Maintenance $^{\text {Other fixed costs }}$ & \% of total fixed cost & 25.00 \\
\hline
\end{tabular}

${ }^{1}$ based on IMEA (2017); ${ }^{2}$ considering that all food products were purchased from third parties, except for forage, the values were based on local market survey and IMEA (2017); ${ }^{3}$ vaccines for clostridiosis, and medicines for respiratory diseases and control of endo- and ectoparasites; ${ }^{4}$ cost of tagging and traceability; ${ }^{5}$ values based on a national minimum wage of R $\$ 937.00$ effective in 2017, plus charges; ${ }^{6}$ calculated according to Pitelli and Bacha (2006); ${ }^{7}$ other fixed costs included all other expenses (telephone, electricity, fuel, lubricants, management, and traceability software according to Sartorello [2016]) *Taxes and fees.

All percentages used in the calculations were reference values in the years 2016 and 2017 and, when not available in the literature, they were obtained from cost estimates and market survey. The income of cattle production was derived exclusively from the sale of the animals to slaughterhouses. The price per arroba (unit of weight corresponding to 15 $\mathrm{kg}$ ) of finished beef cattle in the study region ranged from R\$ 117.54 to R \$ 132.13 in July and November 2017, respectively (IMEA, 2017), including an animal traceability premium of $\mathrm{R} \$ 2.00$ per arroba.

After finalizing the inventory and calculating asset depreciation, the total operating $\operatorname{cost}(\mathrm{TOC}=\mathrm{FC}+\mathrm{VC})$ was calculated (BARBOSA; SOUZA, 2007; adapted from SARTORELLO, 2016). The effective operating cost (EOC) was calculated according to Matsunaga et al. (1976), by subtracting the depreciation from the TOC (EOC $=$ TOC - depreciation). The gross margin (GM) was obtained by subtracting the EOC from the income (GM = income - EOC); the operating profit (OP) was obtained by subtracting TOC from the income (OP = income - TOC), and the total profit (TP) was obtained by subtracting TOC from income and the OC (TP = income - COT - OC). The profitability was calculated by the ratio between the $\mathrm{OP}$ and income (profitability $=\mathrm{OP} /$ income), and the return on investment (ROI) was calculated by the ratio between $\mathrm{OP}$ and initial investment $(\mathrm{ROI}=$ OP/initial investment), as proposed by Barbosa and Souza (2007).
The daily operating cost (DOC) included all operating costs, except for the cost of unfinished cattle, forage, and variable taxes. The cost to maintain one head of cattle per day in the feedlot (CHD) did not include the purchase of cattle, variable taxes, and associated OC (SARTORELLO, 2016). The cost per arroba produced (C@P) was defined by the ratio between TOC (excluding the cost of purchases cattle) and the weight gained during the confinement period. The break-even point, which indicates the value at which livestock production results in neither financial gain nor loss, was determined by the TOC divided by the price of the arroba of finished cattle.

Nominal cash flow was obtained by subtracting income from the EOC. Real cash flow was calculated by correcting the nominal cash flow by an interest rate of $6.0 \%$ per year. Total investment was considered in the year zero. From year 1 to 9, expenses and income were accounted for, including the cost of renewing the assets that depreciated in the corresponding period. The land appreciation was not considered in the analysis. The cash flow in the 9-year period for each simulated confinement system was used to calculate the net present value (NPV, in R\$), internal rate of return (IRR, in \% per year), and discounted payback period (DPP) (in years) (BARBIERI et al., 2016). 
The Monte Carlo technique was used to assess the risk of financial loss when simulating the outcomes of the three projects. This technique generates, through the assessment of numerous scenarios for each project, a sequence of probability distributions, making possible to observe the risk associated before implementing the project (MUN, 2010). The prices of finished and unfinished cattle, and of corn from 2013 to 2017 deflated by the IGP-DI of October 2017 were used. The IGP-DI (General Price Index Domestic Supply) corresponds to inflation in Brazil and it is used to readjust prices over time. A total of 10,000 simulations were randomly generated using the means and respective standard deviations to calculate the OP per animal (in reais), return on investment rate (in \% per year), and profitability (in $\%$ per year) at different space allowances. The financial results were obtained using spreadsheets created in Excel software (Microsoft Corporation ${ }^{\circledR}$, 2010) and were compared by descriptive analysis.

\section{Results and Discussion}

In the absence of data on the economic impact of space allowance for feedlot-finished cattle, the simulations allow predicting the outcomes for different scenarios. In this study, the purchases of cattle and feed were responsible for $86.5 \%$ of the VC (Figure 1), which accounts for most of the TOC. Other variable costs, including animal health management, cleaning feedlot pens, and variable taxes, differed between the three spaces allowance tested (Table 4). The space allowances of 6 and 12 $\mathrm{m}^{2}$ presented a higher cost of health management per animal, because higher stocking density increased the frequency of respiratory problems (MACITELLI, 2015). The cost of cleaning feedlot pens was also higher under these conditions due to the higher animal density, resulting in buildup of mud, feces, and urine (MACITELLI, 2015), requiring more time and effort to clean the feedlot pens (Table 4).

Figure 1. Proportion of variable costs (A), fixed costs (B), opportunity costs (C), and total costs (D) in pens of different sizes $\left(6,12\right.$, and $24 \mathrm{~m}^{2}$ per animal).

A

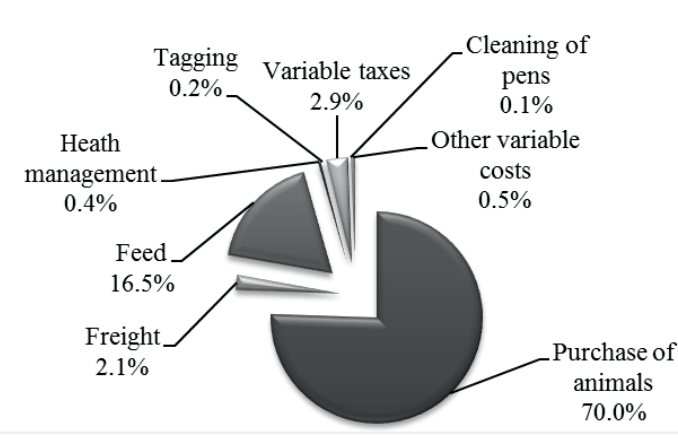

C

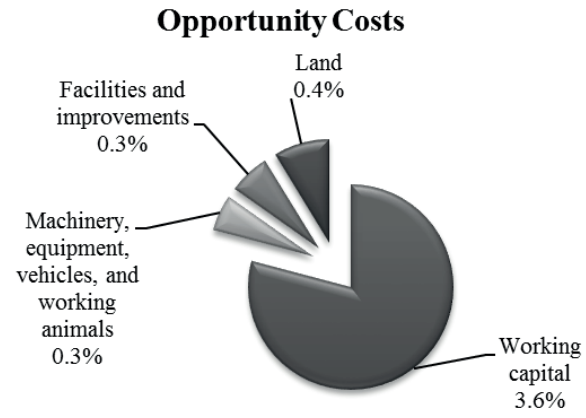

B

Fixed Costs

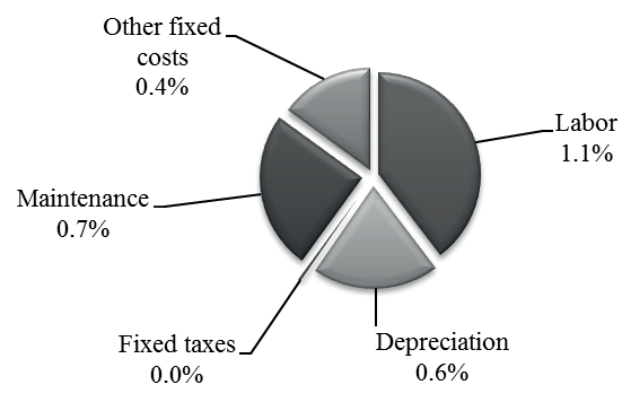

D

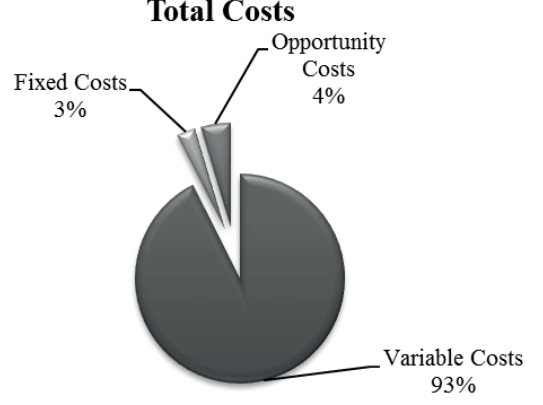


On the other hand, FC increased as space allowance increased (Table 4). Depreciation is an item that compound the FC and corresponds to the financial reserve required to acquire new assets when they reach the end of service life. The land tax also increased as space allowance increased. However, the contribution of FC was lower (approximately $3 \%$ ) than that of TOC (Figure 1) and did not has an important impact on the financial results. EOC per arroba decreased as space allowance increased, corresponding to R\$ 120.00 , R\$ 118.90 , and R\$
118.60 in pens of 6,12 , and $24 \mathrm{~m}^{2}$, respectively. A similar decreasing trend in TOC per arroba was also observed (Table 4). Comparable results were reported for EOC (R\$ 123.90 and $\mathrm{R} \$ 124.20$ per arroba) and TOC (R\$ 124.70 and R\$ 126.90 per arroba) for different beef cattle breeds (MOREIRA et al., 2015) and slaughter weights (PACHECO et al., 2015), respectively. For comparison purposes, the values reported by the authors were deflated by the IGP-DI of November 2017.

Table 4. Estimated annual production cost per animal and arroba (in reais) in pens of three space allowances, 6,12 , and $24 \mathrm{~m}^{2}$ per animal.

\begin{tabular}{lcccccc}
\hline & \multicolumn{3}{c}{$\mathrm{R} \$$ /animal } & \multicolumn{3}{c}{$\mathrm{R} \$$ arroba } \\
\cline { 2 - 7 } & $6 \mathrm{~m}^{2}$ & $12 \mathrm{~m}^{2}$ & $24 \mathrm{~m}^{2}$ & $6 \mathrm{~m}^{2}$ & $12 \mathrm{~m}^{2}$ & $24 \mathrm{~m}^{2}$ \\
\hline VARIABLE COSTS & $2,277.90$ & $2,278.00$ & $2,277.10$ & 117.10 & 116.10 & 115.70 \\
Purchase of cattle & $1,720.40$ & $1,720.40$ & $1,720.40$ & 88.40 & 87.70 & 87.40 \\
Freight & 51.40 & 51.40 & 51.40 & 2.60 & 2.60 & 2.60 \\
Feed & 406.40 & 406.40 & 406.40 & 20.90 & 20.70 & 20.70 \\
Health management & 9.20 & 9.30 & 9.00 & 0.50 & 0.50 & 0.50 \\
Tagging & 5.50 & 5.50 & 5.50 & 0.30 & 0.30 & 0.30 \\
Variable taxes & 72.10 & 72.60 & 72.70 & 3.70 & 3.70 & 3.70 \\
Cleaning of pens & 1.60 & 1.30 & 0.50 & 0.10 & 0.10 & 0.00 \\
Other variable costs & 11.20 & 11.20 & 11.20 & 0.60 & 0.60 & 0.60 \\
\hline FIXED COSTS & 70.10 & 70.20 & 70.30 & 3.60 & 3.60 & 3.60 \\
Labor & 27.80 & 27.80 & 27.80 & 1.40 & 1.40 & 1.40 \\
Depreciation & 13.90 & 14.00 & 14.10 & 0.70 & 0.70 & 0.70 \\
Fixed taxes & 0.25 & 0.270 & 0.30 & 0.00 & 0.00 & 0.00 \\
Maintenance & 17.60 & 17.60 & 17.60 & 0.90 & 0.90 & 0.90 \\
Other fixed costs & 10.50 & 10.50 & 10.50 & 0.50 & 0.50 & 0.50 \\
\hline COST OF OPPORTUNITY & 109.90 & 111.30 & 114.00 & 5.70 & 5.70 & 5.80 \\
Working capital & 88.40 & 88.40 & 88.40 & 4.50 & 4.50 & 4.50 \\
Machinery, equipment, vehicles, and & 6.40 & 6.40 & 6.40 & 0.30 & 0.30 & 0.30 \\
ranch horses & 7.10 & 7.20 & 7.30 & 0.40 & 0.40 & 0.40 \\
Facilities & 8.00 & 9.40 & 12.00 & 0.40 & 0.50 & 0.60 \\
Land & $2,333.00$ & $2,333.20$ & $2,333.40$ & 120.00 & 118.90 & 118.60 \\
\hline EFFECTIVE OPERATING COST & $2,348.00$ & $2,348.20$ & $2,347.50$ & 120.70 & 119.60 & 119.30 \\
TOTAL OPERATING COST & $2,457.90$ & $2,459.50$ & $2,461.50$ & 126.30 & 125.30 & 125.10 \\
TOTAL COST & & & & & & \\
\hline & & & & & \\
\hline
\end{tabular}

DOC was used to measure how efficient were the three space allowances in using the factors of production. Due to the reduced cost for treating sick animals and cleaning feedlot pens, confinement with $24 \mathrm{~m}^{2}$ animal ${ }^{-1}$ space allowance was slightly more efficient $\left(\mathrm{DOC}=\mathrm{R} \$ 1.72\right.$ animal day $\left.{ }^{-1}\right)$ than 6 and $12 \mathrm{~m}^{2}$ animal $^{-1}\left(\mathrm{DOC}=\mathrm{R} \$ 1.73\right.$ animal day ${ }^{-1}$, for both). Sartorello (2016) reported similar results than ours for DOC (R $\$ 1,73$ and 1,72 per animal per day, for São Paulo and Goiás states, respectively). 
The CHD was similar for all space allowance tested in our study (CHD = R \$ 6.45), being lower than the value reported by Sartorello (2016), which was calculated considering the conditions of São Paulo state $(\mathrm{CHD}=\mathrm{R} \$ 8.90)$, where the costs of feed and labor are higher. Higher CHD was also reported by Mader (2011) when assessing the costs of cattle confined under different climatic conditions in spaces of 14, 23, and $33 \mathrm{~m}^{2}$ per animal in the United States and Canada (R\$ 7.50 for all treatments).

The cost of feeding was the same for the three treatments, R\$ 4.73 per animal per day. C@P decreased as space allowance increased $(\mathrm{R} \$ 96.50$, $\mathrm{R} \$ 94.10$, and $\mathrm{R} \$ 93.30$ for 6,12 , and $24 \mathrm{~m}^{2}$ per animal, respectively), this was because the weight gained by cattle during the feedlot period increased as the space allowance increased $(6.50,6.67$ and 6.72 arrobas for 6,12 and $24 \mathrm{~m}^{2}$, respectively). Similar result was observed by Mader (2011), who reported $\mathrm{C} @ \mathrm{P}=\mathrm{R} \$ 102.20$ in $14 \mathrm{~m}^{2}$ and $\mathrm{R} \$ 94.50$ in $23 \mathrm{~m}^{2}$ and $33 \mathrm{~m}^{2}$ per animal, considering an exchange rate of R\$3.30 per dollar. Mader (2011) and Macitelli (2015) reported an increase in the amount of mud when cattle were kept under reduced space allowance in the feedlot pens, this resulted in decrease in weight gain and, consequently, in an increase in the cost of production.

Most of the studies addressing the economic viability of feedlot-finished cattle focused on the roles of diet composition (MISSIO et al., 2009; PACHECO et al., 2014a; ROSA et al., 2017) and slaughter weight (PACHECO et al., 2014b, 2015; FABRICIO et al., 2017), probably because the purchases of cattle and feed represent approximately $87 \%$ of TOC. Studies about the effects of space allowance are scarce. There is a trend among the Brazilian producers to decrease feedlot cattle pen space allowance, probably because they believe that by doing this the operating costs decrease, which is not the case, as demonstrated in the present study.

The OC represents the revenue that the capital invested in the activity would achieve if the capital were applied in alternative activities. This cost increased by approximately $2 \%$ in larger pens (24$\mathrm{m}^{2}$ ), due to the higher cost of facilities and land (Table 2). The total cost per animal (TCA) was also higher in the largest pens - an additional $\mathrm{R} \$ 2.00$ per animal - because the OC composes the TC (Table $4)$.

The gross profit and the $\mathrm{OP}$ increased as space allowance increased (Figure 2); the OP increased $26 \%, 35 \%$ and $7 \%$, when comparing the pen areas of 6 with 12, 6 with 24, and 12 with $24 \mathrm{~m}^{2}$ per animal, respectively. The higher performance in larger pens resulted in larger carcasses weight (MACITELLI, 2015) and, consequently, higher income and profits. The TP was negative in all three feedlot space allowances (Figure 2), indicating that the investment in feedlot-finished cattle pay less than other investments, such as a savings account. Under such economic condition feedlot-finished cattle may be economically viable, but it is not the most attractive investment option (BARBOSA; SOUZA, 2007).

To avoid operational or economic losses, the break-even point in the three feedlot space allowances corresponded to an average daily weight gain (ADWG) of $1.5 \mathrm{~kg}$ and $1.8 \mathrm{~kg}$ and carcass weight of 19 and 20 arrobas for OP and TP, respectively. Given that ADWG and carcass weight in all space allowances were higher than 1.5 $\mathrm{kg}$ and 19 arrobas, respectively, OP was achieved. However, since ADWG and carcass weight did not exceed $1.8 \mathrm{~kg}$ and 20 arrobas, respectively, the TP was not achieved, indicating that the alternative activity would be more rentable.

The initial investment was higher for the feedlot with the largest pens ( $24 \mathrm{~m}^{2}$ per animal), and this was mainly because the larger land area required to build the pens (102 ha) when compared to the pens with 6 and $12 \mathrm{~m}^{2}$ per animal (30 and 60 ha, respectively), which resulted in a TC of $\mathrm{R} \$ 714.70$, $\mathrm{R} \$ 760.50$, and $\mathrm{R} \$ 852.20$ for the three pen space allowances, respectively (Table 5). 
Figure 2. Total operating cost, income, gross margin, operating profit, and total profit per animal (in reais) in pens of three space allowances, 6,12 , and $24 \mathrm{~m}^{2}$ per animal.

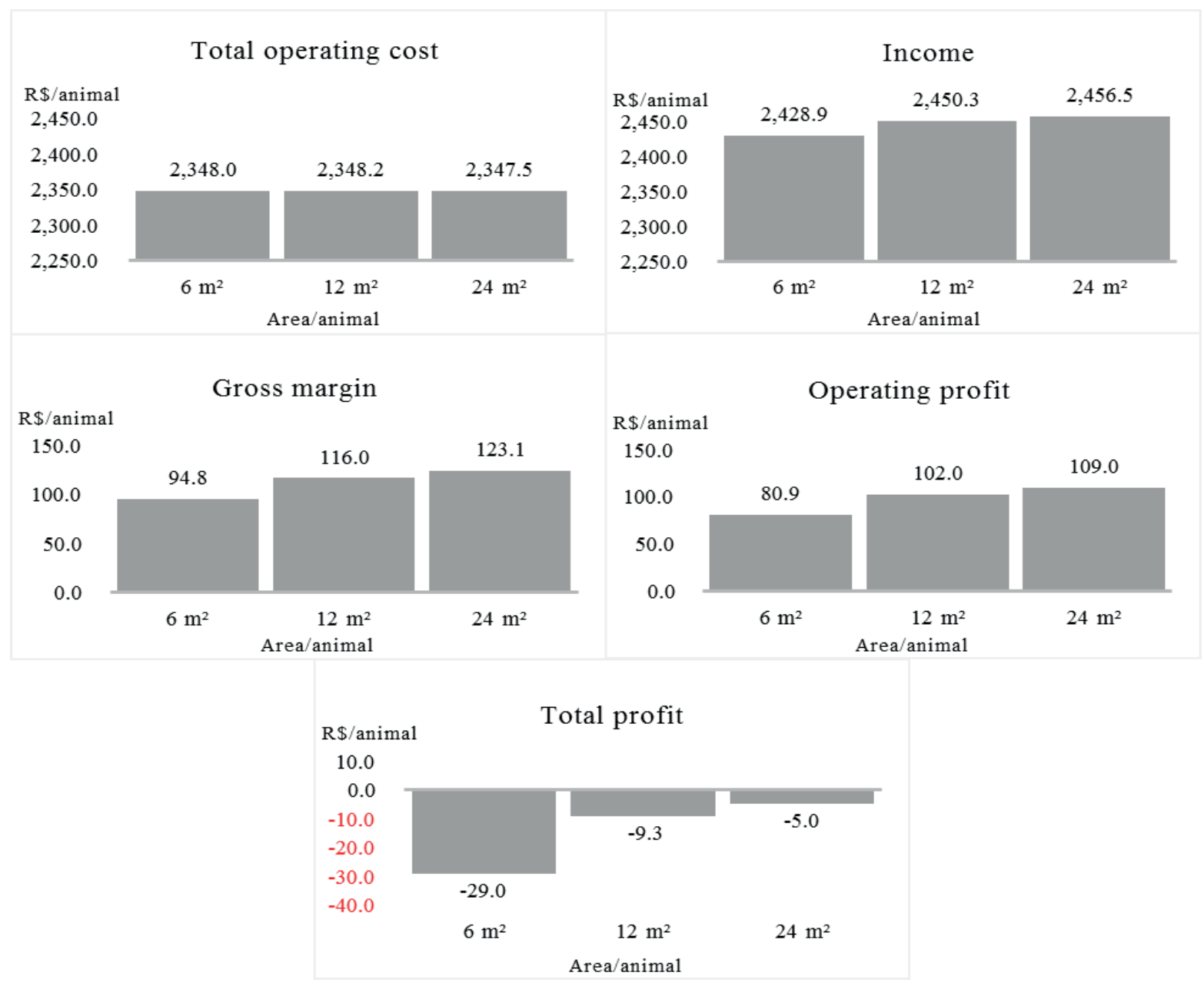

Table 5. Cost per animal (in reais) for the construction of pens of three space allowances $\left(6,12\right.$, and $24 \mathrm{~m}^{2}$ per animal) with capacity for 5,000 animals per cycle.

\begin{tabular}{lccc}
\hline & \multicolumn{2}{c}{$\mathrm{R} \$ /$ animal } \\
\cline { 2 - 4 } Cost & $6 \mathrm{~m}^{2}$ & $12 \mathrm{~m}^{2}$ & $24 \mathrm{~m}^{2}$ \\
\hline Facilities, machinery, and equipment & 347.50 & 347.50 & 347.50 \\
Feedlots pens, feed troughs, and water troughs & 89.50 & 90.90 & 93.80 \\
Vehicles & 9.00 & 9.00 & 9.00 \\
Ranch horses & 2.40 & 2.40 & 2.40 \\
Land & 266.30 & 310.70 & 399.50 \\
\hline Total & 714.70 & 760.50 & 852.20 \\
\hline
\end{tabular}

The joint analysis of economic viability indicators facilitates the decision-making regarding to define the best pen space allowance in feedlotfinished cattle. The values of NPV, which indicates the recovery of the initial investment considering a minimum attractive rate of return (MARR), were all positives and increased as space allowance increased ( $\mathrm{R} \$ 279.40, \mathrm{R} \$ 400.60$, and $\mathrm{R} \$ 402.90$ for 6,12 , and $24 \mathrm{~m}^{2}$ per animal, respectively). Although the three pen space allowances were considered 
economically satisfactory, higher NPV per animal is preferable. Previous studies showed that the NPV for confined cattle in Brazil varied from $\mathrm{R} \$ 43.20$ to $\mathrm{R} \$ 594.00$, depending on the levels of concentrate in the diet and slaughter weights (PACHECO et al., 2015; BARBIERI et al., 2016; ROSA et al., 2017).

The IRR, which is the ratio that equalizes the inflow and outflow, was higher for $12 \mathrm{~m}^{2}$ per animal (27\%) when compared to $6(22 \%)$ and 24 $\mathrm{m}^{2}$ per animal $(25 \%)$. The higher IRR relative to MARR ( $6 \%$ per year) indicates that the three pen space allowances were economically feasible. It is well known that the shorter the time to recover invested capital, the lower the risk of a project. In this sense, we observed that DPP of the three pen space allowances were lower than the maximum period of analysis, with the lowest value showed by $12 \mathrm{~m}^{2}$-pens ( 3 years), followed by $24 \mathrm{~m}^{2}$ (4 years) and $6 \mathrm{~m}^{2}$ (5 years).

It should be highlighted that the feasibility analyses did not consider land valuation $(9.5 \%$ per year, according to ANUALPEC [2017]). Nonetheless, this parameter is critical and could bring financial gains in feedlots with larger pens, especially when located in valued lands, such as in the Central-West, Southeast, and South regions of Brazil (RAMOS; NAVARRO, 2018). In addition to the economic benefits demonstrated in this study, increasing feedlot pen space allowances has also potential to improve the image of cattle production chain among the consumers (PARANHOS da COSTA, 2004).

The risk of financial loss (Figure 3) was assessed by analyzing the distribution of average OP per animal derived from 10,000 simulations with different probability distributions and considering variations in the selling price of finished cattle $(\mathrm{R} \$$ $146.30 \pm 6.30$ ), and in the costs of unfinished cattle $(\mathrm{R} \$ 156.60 \pm 6.70)$, and corn $(\mathrm{R} \$ 34.6 \pm 3.90)$. The largest pens were more efficient, with higher OP per animal $(\mathrm{R} \$ 100.40 \pm 267.50)$ when compared to 6 $\mathrm{m}^{2}$ and $12 \mathrm{~m}^{2}$ pens $(\mathrm{R} \$ 69.20 \pm 266.60$ and $\mathrm{R} \$ 92.70$ \pm 267.30 , respectively). The average profitability was also higher in pens of $24 \mathrm{~m}^{2}(1.5 \%$ per year $)$ than in those of $6 \mathrm{~m}^{2}(0.4 \%$ per year $)$ and $12 \mathrm{~m}^{2}$ (1.2\% per year).

Figure 3. Distribution of the average operating profit per animal (in reais) in pens of three space allowances, 6 , 12 , and $24 \mathrm{~m}^{2}$ per animal.

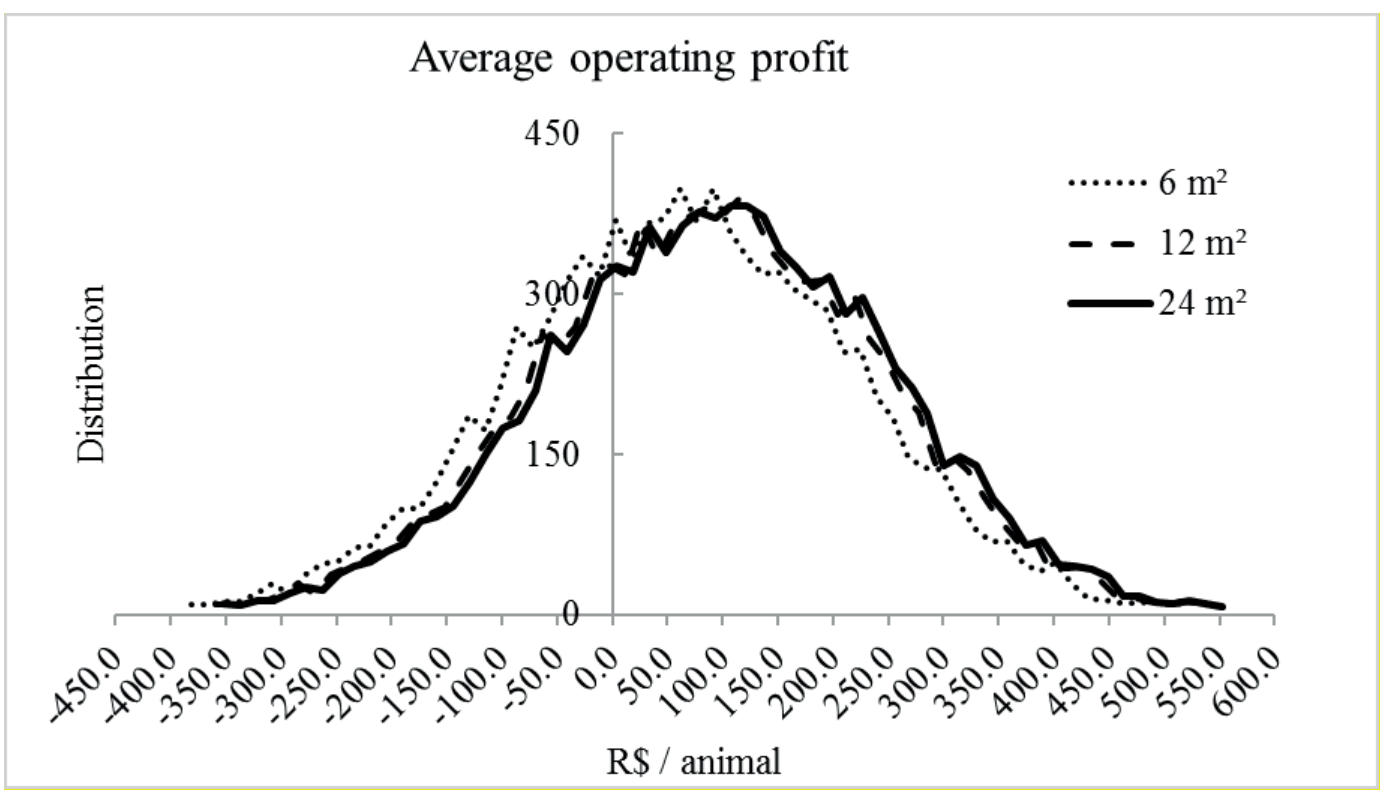


According to the financial results from the 10,000 simulations, the probability of profit was higher in larger pens, resulting in a lower risk of financial loss (Figure 4). Pacheco et al. (2014b) did economic analyses of cattle feedlots reporting a probability of positive results ranging from $27 \%$ to $70 \%$, depending on slaughter weights of animals.

Figure 4. Probability of financial gain or loss in beef cattle feedlot production in pens of three space allowances, 6 , 12 , and $24 \mathrm{~m}^{2}$ per animal.

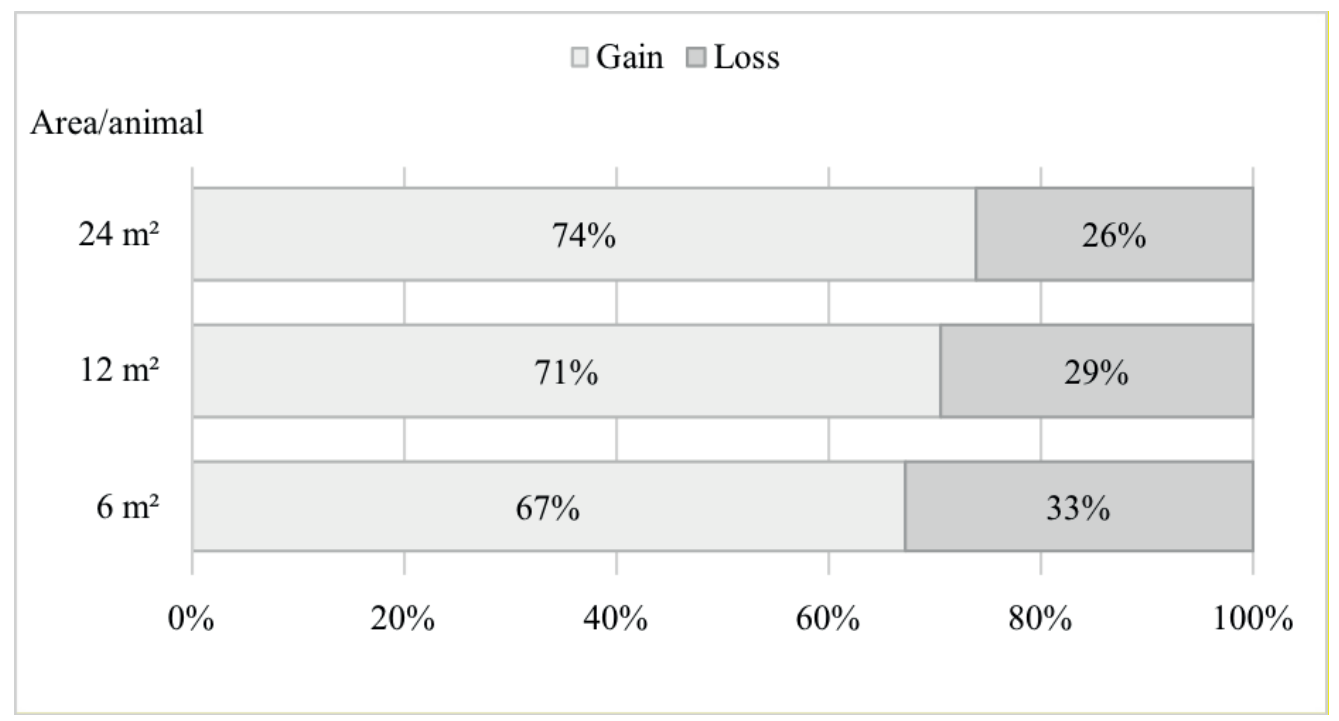

The economic success of cattle confinement is related to the profitability of the activity, which is directly dependent on the income. Once the slaughter weight strongly affects the economic results of feedlot finished cattle, as previously demonstrated in sensitivity analyses by Silva et al. (2017), and that cattle performance and, consequently, the carcass weight, increased as space allowance increased (MACITELLI, 2015), it is expected that, besides improving animal welfare (MACITELLI, 2015), larger pens would also provide better economic results for the producers, and this was confirmed by the results of our study.

\section{Conclusion}

The analyses of economic feasibility by simulating different feedlot-finished cattle production conditions allow us to recommend an increase in space allowance per head of cattle in feedlot pens to, at least, $24 \mathrm{~m}^{2}$ animal ${ }^{-1}$, because larger space increases profitability and decreases the risk of economic loss.

\section{Acknowledgments}

The lead author was a post-doc in the Graduate Program in Animal Science at Faculty of Agricultural and Veterinary Sciences, São Paulo State University, receiving a scholarship granted by the Coordination for the Improvement of Higher Education Personnel (CAPES). We thank Boehringer Ingelheim for the financial support.

\section{References}

ANUALPEC. Anuário da Pecuária Brasileira 2016. 23. ed. São Paulo: IEG/FNP, 2016. 
ANUALPEC. Anuário da Pecuária Brasileira 2017. 24. ed. São Paulo: IEG/FNP, 2017.

BARBIERI, R. S.; CARVALHO, J. B.; SABBAG, O. J. Análise de viabilidade econômica de um confinamento de bovinos de corte. Interações, Campo Grande, v. 17, n. 3, p. 357-369, 2016. DOI: 10.20435/1984-042X-2016v.17-n.3(01)

BARBOSA, F. A.; SOUZA, R. C. Administração de fazendas de bovinos: leite e corte. Viçosa, MG: Aprenda Fácil, 2007. 342 p.

FABRICIO, E. A.; PACHECO, P. S.; VAZ, F. N.; LEMES, D. B.; CAMERA, A.; MACHADO, G. I. O. Financial indicators to evaluate the economic performance of feedlot steers with different slaughter weights. Ciência Rural, Santa Maria, v. 47, n. 3, p. 1-6, 2017. DOI: $10.1590 / 0103-8478 \mathrm{cr} 20160516$

FELL, L. R.; COLDITZ, I. G.; WALKER, K. H.; WATSON, D. L. Associations between temperament, performance and immune function in cattle entering a commercial feedlot. Animal Production Science, Clayton, v. 39, n. 7, p. 795-802, 1999. DOI: 10.1071/EA99027

FISHER,A.D.; CROWE, M.A.; O'KIELY,P.; ENRIGHT, W. J. Growth, behavior, adrenal and immune responses of finishing beef heifers housed on slatted floors at 1.5, $2.0,2.5$ or $3.0 \mathrm{~m}^{2}$ space allowance. Livestock Production Science, Amsterdam, v. 51, n. 1-3, p. 245-254, 1997. DOI: 10.1016/S0301-6226(97)00052-3

FRASER, A. F. Farm animal behavior. Londres: Ballière Tindall, 1980. $196 \mathrm{p}$.

GUPTA, S.; EARLEY, B.; CROWE, M. A. Pituitary, adrenal, immune and performance responses of mature Holstein $\times$ Friesian bulls housed on slatted floors at various space allowances. The Veterinary Journal, London, v. 173, n. 3, p. 594-604, 2007. DOI: 10.1016/j. tvj1.2006.02.011

HICKEY, M. C.; EARLEY, B.; FISHER, A. D. The effect of floor type and space allowance on welfare indicators of finishing steers. Irish Journal of Agriculture and Food Research, Carlow, v. 42, p. 89-100, 2003.

HOFFMANN, R.; SERRANO, O.; NEVES, E. M.; THAME, A. C. M.; ENGLER, J. J. C. Administração da empresa agrícola. 6. ed. São Paulo: Pioneira, 1987. 326 p.

INSTITUTO MATO-GROSSENSE DE ECONOMIA AGROPECUÁRIA - IMEA. Boi custos de produção. Cuiabá-MT: IMEA, 2017. Available at: http://www.imea. com.br/imea-site/relatorios-mercado-detalhe? $\mathrm{c}=2 \& \mathrm{~s}=3$. Accessed at: 12 apr. 2018.

INGVARTSEN, K. L.; ANDERSEN, H. R. Space allowance and type of housing for growing cattle. A review of performance and possible relation to neuroendocrine function. Acta Agriculturae Scandinavica, Section A Animal Science, London, v. 43, n. 2, p. 65-80, 1993. DOI: 10.1080/09064709309410147

KONDO, S.; SEKINE, J.; OKUBO, M.; ASAHIDA, $\mathrm{Y}$. The effect of group size and space allowance on the agonistic and spacing behavior of cattle. Applied Animal Behaviour Science, Amsterdam, v. 24, n. 2, p. 127-135, 1989. DOI: $10.1016 / 0168-1591(89) 90040-3$

LINDBERG, A. C. Group life. In: KEELING, L; GONYOU, H. W. (Ed.). Social behavior in farm animals. Wallingford: CABI Publishing, 2001. p. 37-54.

MACITELLI, F. Implicações da disponibilidade de espaço no confinamento de bovinos de corte. 2015. Tese (Doutorado em Zootecnia) - Faculdade de Ciências Agrárias e Veterinárias, Universidade Estadual Paulista Júlio de Mesquita Filho, Jaboticabal.

MADER, T. L. Environmental stress in confined beef cattle. Journal of Animal Science, Champaign, v. 81, p. E110-E119, 2003. Supplement 2. DOI: 10.2527/2003.8114_suppl_2E110x

MADER, T. L. Mud effects on feedlot cattle. In: MADER, T. L. 2011 nebraska beef cattle report. Lincoln: University of Nebraska, 2011. Available at: https:// digitalcommons.unl.edu/cgi/viewcontent.cgi? article $=15$ 97\&context=animalscinbcr. Accessed at: 10 mar. 2018.

MATSUNAGA, M.; BEMELMANS, P. F.; TOLEDO, P. E. N.; DULLEY, R. D.; OKAWA, H.; PEDROSO, I. A. Metodologia de custo utilizada pelo IEA. Agricultura em São Paulo, São Paulo, v. 23, n. 1, p. 123-139, 1976.

MISSIO, R. L.; BRONDANI, I. L.; FREITAS, L. S.; SACHET, R. H.; SILVA, J. H. S.; RESTLE, J. Desempenho e avaliação econômica da terminação de tourinhos em confinamento alimentados com diferentes níveis de concentrado na dieta. Revista Brasileira de Zootecnia, Viçosa, MG, v. 38, n. 7, p. 1309-1316, 2009. DOI: $10.1590 / \mathrm{S} 1516-35982009000700021$

MOREIRA, F. S.; OLIVEIRA, M. N. N. F.; VILLELA, S. D. J.; BARBOSA, F. A.; MOURTHE, M. H. F.; DINIZ, F. B. Desempenho produtivo e econômico de três grupos genéticos de bovinos recriados a pasto com suplementação e terminados em confinamento. Arquivos Brasileiros de Medicina Veterinária e Zootecnia, Belo Horizonte, v. 67, n. 1, p. 140-148, 2015. DOI: 10.1590/1678-7250

MORMÈDE, P.; ANDANSON, S.; AUPÉRIN, B.; BEERDA, B.; GUÉMENÉ, D.; MALMKVIST, J.; MANTECA, X.; MANTEUFFEL, G.; PRUNET, P.; VAN REENEN, C. G.; RICHARD, S.; VEISSIER, I. Exploration of the hypothalamic-pituitary-adrenal 
function as a tool to evaluate animal welfare. Physiology \& Behavior, Amsterdam, v. 92, n. 3, p. 317-339, 2007. DOI: $10.1016 /$ j.physbeh.2006.12.003

MUN, J. Modeling risk: applying Monte Carlo risk simulation, strategic real options, stochastic forecasting, and portfolio optimization. $2^{\text {th }}$ ed. Hoboken: John Wiley \& Sons, Inc., 2010. 976 p

PACHECO, P. S.; PASCOAL, L. L.; RESTLE, J.; VAZ, F. N.; ARBOITTE, M. Z.; VAZ, R. Z.; SANTOS, J. P. A.; OLIVEIRA, T. M. L. Risk assessment of finishing beef cattle in feedlot: slaughter weights and correlation amongst input variables. Revista Brasileira de Zootecnia, Viçosa, MG, v. 43, n. 2, p. 92-99, 2014b. DOI: 10.1590/ S1516-35982014000200007

PACHECO, P. S.; SILVA, R. M.; PADUA, J. T.; RESTLE, J.; TAVEIRA, R. Z.; VAZ, F. N.; PASCOAL, L. L.; OLEGARIO, J. L.; MENEZES, F. R. Análise econômica da terminação de novilhos em confinamento recebendo diferentes proporções de cana de açúcar e concentrado. Semina: Ciências Agrárias, Londrina, v. 35, n. 2, p. 9991011, 2014a. DOI: 10.5433/1679-0359.2014v35n2p999

PACHECO, P. S.; VAZ, F. N.; RESTLE, J.; ÁVILA, M. M.; OLEGARIO, J. L.; MENEZES, F. R.; VALENÇA, K. G.; LEMES, D. B.; VARGAS, F. V. de. Deterministic economic analysis of feedlot red Angus Young steers: slaughter weights and bonus. Ciência Rural, Santa Maria, v. 45, n. 3, p. 492-498, 2015. DOI: 10.1590/0103$8478 \mathrm{cr} 20140631$

PARANHOS da COSTA, M. J. R. Comportamento e bem-estar de bovinos e suas relações com a produção de qualidade. In: REUNIÃO DA SOCIEDADE BRASILEIRA DE ZOOTECNIA, 41., Campo Grande, 2004. Anais... Campo Grande: Sociedade Brasileira de Zootecnia, 2004. p. 260-268.

PITELLI, M. M.; BACHA, C. J. C. Análise dos principais tributos incidentes na cadeia de carne bovina brasileira. In: CONGRESSO DA SOCIEDADE BRASILEIRA DE ECONOMIA E SOCIOLOGIA RURAL, 56., Fortaleza, 2006. Anais... Fortaleza: SOBER, 2006. p. 1-20.

QUINTILIANO, M. H.; PARANHOS da COSTA, M. J. R. Manejo racional de bovinos de corte em confinamentos: produtividade e bem-estar animal. In: SIMPÓSIO DO NÚCLEO DE ESTUDOS EM BOVINOCULTURA, SINEBOV, 4., 2007, Seropédica. Anais... Seropédica: UFRRJ, 2007. CD-ROM.
RAMOS, C. S.; NAVARRO, K. Terras sobem mais na velha fronteira agrícola do Brasil. São Paulo: Valor Econômico, 2018. Retrieved from: http:/www.valor. com.br/agro/5253119/terras-sobem-mais-na-velhafronteira-agricola-do-brasil. Accessed in: 12 abr. 2018.

RASMUSSEN, R.; FONTES, A.; CORDINGLEY, B. Beefing up in Brazil - feedlots to drive industry growth. Utrecht: Rabobank International: Global Department of Food \& Agribusiness Research and Advisory, 2014. 7p. (Rabobank International - Nota, 459).

ROSA, J. R. P.; PACHECO, P. S.; FABRICIO, E. A.; CAMERA, A.; LEMES, D. B. Risk analysis of the economic viability of feedlot Aberdeen Angus steers fed with different proportions of concentrate. Bioscience Journal, Uberlândia, v. 33, n. 3, p. 660-669, 2017. DOI: 10.14393/BJ-v33n3-34547

SARTORELlO, G. L. Desenvolvimento de modelo de cálculo e custos de produção para bovinos de corte em confinamento. 2016. Dissertação (Mestrado em Zootecnia) - Faculdade de Medicina Veterinária e Zootecnia da Universidade de São Paulo, Pirassununga.

SILVA, R. M.; TAVEIRA, R. Z.; VAZ, F. N.; FABRICIO, E. A.; MIOLLO, J. R.; CAMERA, A.; PACHECO, P. S. Stochastic simulation of the economic viability of feedlot steers fed with different proportions of concentrate. Bioscience Journal, Uberlândia, v. 33, n. 1, p. 125-134, 2017. DOI: 10.14393/BJ-v33n1a2017-33608

SINDICATO DA INDÚSTRIA DA CONSTRUÇÃO CIVIL DO ESTADO DO MATO GROSSO - SINDUSCON. Composição de custos unitários básicos $\left(\mathrm{CUB} / \mathrm{m}^{2}\right)$ : Valores em Reais. Cuiabá, MT: SINDUSCON-MT. 2013. Available at: http://memoria. cub.org.br/p_reports.php?sid=13\&id=38. Accessed at: 12 apr. 2018.

VANHONACKER, F.; VERBEKE, W.; VAN POUCKE, E.; BUIJS, S.; TUYTTENS, F. A. M. Societal concern related to stocking density, pen size and group size in farm animal production. Livestock Science, Amsterdam, v. 123, n. 1, p. 16-22, 2009. DOI: 10.1016/j.livsci.2008.09.023

VANHONACKER, F.; VERBEKE, W.; VAN POUCKE, E.; TUYTTENS, F. A. M. Do citizens and farmers interpret the concept of farm animal welfare differently? Livestock Science, Amsterdam, v. 116, n. 1, p. 126-136, 2008. DOI: 10.1016/j.livsci.2007.09.017 
